\title{
МОДИФІКАЦІЯ ФАКТОРІВ РИЗИКУ СЕРЦЕВО-СУДИННИХ УСКЛАДНЕНЬ В ПЛАНІ ОПТИМІЗАЦІЇ ЛІКУВАННЯ ХВОРИХ ІЗ ХРОНІЧНОЮ ХВОРОБОЮ НИРОК СЕАНСАМИ ПРОГРАМНОГО ГЕМОДІАЛІЗУ
}

І. Л. Кучма

\author{
Національна медична академія післядипломної освіти імені П. Л. Шупика
}

\begin{abstract}
Вивчено вплив індивідуально підібраних та стандартних лікувальних програм гемодіалізу на фрактори ризику виникнення серцево-судинних ускладнень у хворих із хронічною хворобою нирок. Зроблено висновки про те, що індивідуально підібрані параметри по часу проведення діалізу, площі, кліренсових та ультрафільтраційних властивостей діалізатора, електролітного складу діалізуючого розчину дозволяють отримувати кращі результати по корекції потенційно модифікованих факторів ризику у пацієнтів з хронічною хворобою нирок, котрі лікуються сеансами програмного гемодіалізу.
\end{abstract}

Ключові слова: хронічна хвороба нирок, серцево-судинні ускладнення, індивідуальні програми гемодіалізу.

\section{МОДИФИКАЦИЯ ФАКТОРОВ РИСКА СЕРДЕЧНО-СОСУДИСТЫХ ОСЛОЖНЕНИЙ В ПЛАНЕ ОПТИМИЗАЦИИ ЛЕЧЕНИЯ БОЛЬНЫХ С ХРОНИЧЕСКОЙ БОЛЕЗНЬЮ ПОЧЕК СЕАНСАМИ ПРОГРАММНОГО ГЕМОДИАЛИЗА}

И. Л. Кучма Национальная медицинская академия последипломного образования имени П. Л. Шупика

\begin{abstract}
Количество больных с хронической болезнью почек (ХБП), получающих заместительную терапию сеансами программного диализа в Украине, постоянно увеличивается. Усовершенствование методов почечной заместительной терапии (ПЗТ) хронической болезни почек, в частности использование современных диализных технологий, привело к значительному увеличению продолжительности жизни пациентов. Вместе с тем, смертность от этого заболевания остается довольно высокой. В ее структуре значительное место занимают сердечно-сосудистые заболевания по данным Национального реестра больных с хронической болезнью почек, в 2011 году она составила $72 \%$. В этой связи становится актуальным определение факторов риска возникновения этих осложнений и поиск новых методик, обеспечивающих их профилактику. Автором изучено влияние индивидуально подобранных и стандартных лечебных программ гемодиализа на факторы риска возникновения сердечно-сосудистых осложнений у больных с ХБП. Сделаны выводы о том, что индивидуально подобранные параметры по времени проведения гемодиализа, клиренсовых и ультрафильтрационных свойствах диализатора, электролитному составу диализирующего раствора позволяют достигать лучших результатов в коррекции фракторов риска у пациентов с ХБП.
\end{abstract}

Ключевые слова: хроническая болезнь почек, сердечно-сосудистые осложнения, индивидуальные программы гемодиализа.

\section{MODIFICATION OF RISK FACTORS FOR CARDIOVASCULAR COMPLICATIONS OPTIMIZATION PLAN PATIENTS WITH CHRONIC KIDNEY DISEASE HEMODIALYSIS SESSION}

\author{
I. L. Kuchma \\ National Medical Academy of Postgraduate Education by P. L. Shupyk
}

\begin{abstract}
The number of patients with chronic kidney disease (CKD) in substitution therapy sessions dialysis program in Ukraine is growing. Improvement of methods of renal replacement therapy (RRT), chronic kidney disease, in particular, the use of modern dialysis technology has led to a significant increase in the life expectancy of patients. However, the mortality of the disease remains high. In its structure heavily reliant on cardiovascular disease, according to the National registry of patients with chronic kidney disease in 2011 it was $72 \%$. In this regard, there is actual determination of risk factors for these complications and the search for new methods to ensure their prevention. The author studied the effect of individually tailored and standard hemodialysis treatment programs on the risk factors of cardiovascular complications in patients with
\end{abstract}

(C) І. Л. Кучма 
CKD. It is concluded that the custom-fitted options at the time of hemodialysis and ultrafiltration properties klirensovyh dialyzer electrolyte composition of the dialysate can achieve better results in the management of risk factors in patients with CKD.

Key words: chronic kidney disease, cardiovascular complications, individual programs hemodialysis.

Вступ. Кількість хворих, які отримують лікування сеансами програмного гемодіалізу, в Україні постійно зростає. Так, за даними Національного реєстру хворих на хронічну хворобу нирок за 2011 рік кількість таких хворих станом на кінець 2011 року становить 4195 чоловік. В 2011 році в Україні померло 346 чоловік, пролікованих сеансами гемодіалізу, що складає 8,2 \% від усієї кількості пацієнтів, які отримували лікування цим методом. Серед них 72 \% - внаслідок причин серцево-судинних захворювань, внаслідок цереброваскулярних захворювань - 11,8 \%, новоутворень - 1,7 \%, інфекційних хвороб - 0,9 \%, інші причини - 13,6 \% (Національний реєстр хворих на хронічну хворобу нирок за 2011 рік). Отже, основна причина летальності - серцево-судинні захворювання, i частка їх в загальній структурі летальності дуже висока. Очевидно, що для зменшення смертності, продовження тривалості життя пацієнтів на гемодіалізі необхідно в першу чергу вирішувати питання зменшення смертності, спричиненої серцево-судинними захворюваннями.

В розвитку серцево-судинної патології у хворих 3 хронічною хворобою нирок виділяють традиційні та нетрадиційні фактори ризику. До традиційних віднесено похилий вік, чоловічу стать, артеріальну гіпертензію, високий холестерин ліпопротеїдів низької щільності, ускладнений сімейний анамнез щодо ішемічної хвороби серця, гіпертрофію лівого шлуночка міокарда тощо. До нетрадиційних факторів ризику виникнення серцевосудинних ускладнень у пацієнтів 3 хронічною хворобою нирок відносять порушення електролітного балансу, оксидативний стрес, реакцію запалення (C-peактивний білок), тромбогенні фактори, порушення сну, зміна балансу окис азоту/ендотелін (1) та деякі інші.

Зазначені фактори ризику доречно оцінювати з точки зору можливості чи неможливості лікувального впливу на них в процесі проведення лікування гемодіалізом, тобто як немодифіковані та модифіковані чи потенційно модифіковані. До немодифікованих відносимо похилий вік, чоловічу стать, цукровий діабет, менопаузу, ускладнений сімейний анамнез щодо ішемічної хвороби серця, стан пацієнта перед початком нирковозамісної терапії.

До переліку модифікованих віднесено артеріальну гіпертензію $(2,5)$, порушення ліпідного обміну (зниження рівня ліпопротеїдів високої щільності і підви- щення рівня ліпопротеїдів низької щільності) (4), куріння (1), обмежену фізичну активність (1), структурні та функціональні зміни міокарда (гіпертрофію лівого шлуночка міокарда, гіпертрофію міжпередсердної перегородки, індекс маси лівого шлуночка (6), мікроальбумінурію, анемію, порушення фосфорнокальцієвого обміну, перевантаження позаклітинного об'єму рідини, порушення електролітного балансу, оксидативний стрес, С-реактивний білок та запалення, тромбогенні фактори, порушення сну.

Окрім того, деякі автори відносять до переліку модифікованих факторів ризику у пацієнтів, що отримують лікування сеансами гемодіалізу, якість надання медичної допомоги на додіалізному етапі, забезпечення необхідної діалізної дози (7), тривалість сеансу гемодіалізу (8), якість і правильно підібрані параметри діалізного розчину (9), нутриційний статус (10), альбумін плазми крові (11).

Мета роботи. Порівняти показники результатів лікування пацієнтів із хронічною хворобою нирок (ХХН) при використанні індивідуально підібраних та стандартних лікувальних програм гемодіалізу.

Матеріал і методи дослідження. Нами проведено порівняння 2 груп хворих з різних відділень гемодіалізу в одному місті, котрі отримували лікування протягом 2011 року.

В першу групу хворих увійшли 85 пацієнтів, котрі отримували лікування у відділенні гемодіалізу з індивідуальним підбором лікувальних програм.

Індивідуалізація програми гемодіалізу полягала в тому, що при призначенні лікування хворим індивідуально підбирались тривалість сеансу (від 5 до 8 годин), профіль концентрації натрію хлориду та профіль концентрації бікарбонату в діалізному розчині, профіль температури, індивідуально визначалась швидкість перфузії крові (від 250 до 350 мл на хв). Частота сеансів у I групі була такою ж, як і при використанні стандартних методик, а тривалість сеансів у $93 \%$ пацієнтів була різною: у 26 (30,5 \%) осіб вона складала 5 год, упродовж 6 годин діаліз тривав у 35 (41\%) хворих, 12 пацієнтам (14\%) його проводили протягом 7 год, а 6 (7,5 \%) чол. - 8 годин.

Другу групу склали 60 пацієнтів, які отримували лікування згідно стандартних локальних протоколів відділення з наступною програмою лікування: сеанси проводились 3 рази на тиждень по 4 години із ста- 
більною концентрацією натрію хлориду в діалізуючому розчині 140 ммоль/л, концентрацією натрію бікарбонату 34 ммоль/л.

В обох групах порівнювали тривалість життя на діалізі, рівні гемоглобіну, забезпеченості діалізною дозою, кількість епізодів інтрадіалізної гіпотензії га гіпертензії на діалізі, нутриційний статус, корекцію артеріальної гіпертензії, смертність в даній когорті хворих. Пацієнти обох груп не відрізнялись за віком, він складав від 18 до 64 років, а 6 пацієнтів першої групи (7\%) та 2 другої групи (3\%) мали більше 64 років.

Що стосується тендерного питання, то обидві групи пацієнтів були рівноцінними для порівняння.
Результати та обговорення. Найчастішими причинами, що призвели до хронічної хвороби нирок, в обох групах були: хронічний пієлонефрит - у 32 (37,6 \%) в першій та $23(38,4 \%)$ у другій групі, діабетична нефропатія - у 12 (15,3\%) пацієнтів першої та $10(16,7$ \%) другої групи. Полікістоз нирок зустрічався у 15 (17,6\%) випадках в першій та в 9 (15\%) у другій групі, хронічний пієлонефрит - у 5 (5,9\%) та 8 $(13,3 \%)$ відповідно. Серед причин відмічені також гіпертензивна нефропатія, системні захворювання та інші.

Частота причин виникнення ХХН відображена в таблиці 1.

Таблиця І. Причини хронічної хвороби нирок

\begin{tabular}{|c|c|c|c|c|}
\hline \multirow[t]{2}{*}{ Нозологічна форма } & \multicolumn{2}{|c|}{$\begin{array}{c}\text { I група хворих } \\
\text { (індивідуальні програми) }\end{array}$} & \multicolumn{2}{|c|}{$\begin{array}{c}\text { II група гаорих } \\
\text { (стандартне лікування) }\end{array}$} \\
\hline & абсолютне число & $\%$ & абсолютне число & $\%$ \\
\hline $\begin{array}{l}\text { Кількість хворих в } \\
\text { досліджуваній групі }\end{array}$ & 85 & 100 & 60 & 100 \\
\hline Хронічний гломерулонефрит & 32 & 37,6 & 23 & 38,4 \\
\hline Діабетична нефропатія & 12 & 15,3 & 10 & 16,7 \\
\hline Гіпертензивна нефропатія & 2 & 2,4 & 2 & 3,3 \\
\hline Хронічний пієлонефрит & 5 & 5,9 & 8 & 13,3 \\
\hline Полікістоз нирок & 15 & 17,6 & 9 & 15 \\
\hline Системні захворювання & 4 & 4,7 & & 0 \\
\hline Інші & 14 & 16,5 & 8 & 13,3 \\
\hline
\end{tabular}

При порівнянні стану пацієнтів перед початком нирковозамісної терапії (табл. 2), виявили, що в групі пацієнтів, які отримували лікування за індивідуальними програмами, значно більший відсоток хворих із високою некоригованою гіпертензією (на 29 \% більше). На 2,4 відсотка менше осіб із ішемічною хворобою серця, на 4,2 \% менше пацієнтів, котрі розпочали лікування діалізом з клубочковою фільтрацією менше 12 мл/хв. Проте, за всіма іншими показника- ми (ступінь анемії, гіпоальбумінемія, гіпопротеїнемія, наявність перикардиту, плевриту, анасарки, нефротичного синдрому) відсоток пацієнтів 3 в групі з індивідуальними програмами значно вищий, що свідчить про те, що у групу, котра лікувалась за індивідуальними програмами, потрапили пацієнти у більш тяжкому стані і з більшим загальним ризиком серцевосудинних ускладнень.

Таблиця 2. Фактори ризику, наявні у пацієнтів перед початком нирково-замісної терапії

\begin{tabular}{|c|c|c|c|c|}
\hline \multirow[t]{2}{*}{ Фактори ризику } & \multicolumn{2}{|c|}{$\begin{array}{c}\text { I група хворих } \\
\text { (індивідуальні програми) }\end{array}$} & \multicolumn{2}{|c|}{$\begin{array}{c}\text { II група хворих } \\
\text { (стандартне лікування) }\end{array}$} \\
\hline & абсолютне число & $\%$ & абсолютне число & $\%$ \\
\hline $\begin{array}{l}\text { Некоригована артеріальна гшертензія } \\
(\mathrm{AT}>) \text { 179/109 мм рт. ст. }\end{array}$ & 33 & 38,8 & 4 & 6,7 \\
\hline Ішемічна хвороба серця & 15 & 17,6 & 12 & 20 \\
\hline Клубочкова фільтрація менше 12 мл/хв & 63 & 74,1 & 47 & 78,3 \\
\hline Альбумін менше 30 г/л & 17 & 20 & 3 & 5 \\
\hline Загальний білок менше 60 г/л & 16 & 18,8 & 3 & 5 \\
\hline Гемоглобін від 70 до 90 г/л & 29 & 34,1 & 14 & 23,3 \\
\hline Гемоглобін до 70 г/л & 34 & 40 & 1 & 1,7 \\
\hline Перикардит & 12 & 14,1 & 2 & 3,3 \\
\hline Нефротичний синдРом & 17 & 20 & 2 & 3,3 \\
\hline
\end{tabular}


Для порівняння результатів лікування індивідуальним підбором лікувальних програм та стандартними методиками оцінювали рівень артеріальної гіпертензії в обох групах. Виявилось, що в групі хворих, які от- римували лікування за індивідуальними програмами діалізу, артеріальна гіпертензія була суттєво менша, порівняно з пацієнтами, яким лікування проводили за стандартними методиками (табл. 3).

Таблиця 3. Порівняльна оцінка результатів лікування пацієнтів із ХХН за стандартними методиками та індивідуальними програмами гемодіалізу

\begin{tabular}{|c|c|c|c|c|c|}
\hline \multirow{2}{*}{\multicolumn{2}{|c|}{ Показник }} & \multicolumn{2}{|c|}{$\begin{array}{c}\text { I група хворих } \\
\text { (індивідуальні програми) }\end{array}$} & \multicolumn{2}{|c|}{$\begin{array}{c}\text { П група хворих } \\
\text { (стандартне лікування) }\end{array}$} \\
\hline & & абсолютне число & $\%$ & абсолютне число & $\%$ \\
\hline \multicolumn{2}{|c|}{ Коригована артеріальна гіпертензія } & 78 & 92 & 10 & 16,6 \\
\hline \multicolumn{2}{|c|}{$\begin{array}{l}\text { Застосування еритропоетину для корекції } \\
\text { анемії }\end{array}$} & 28 & 33 & 39 & 65,2 \\
\hline \multirow[t]{2}{*}{ Гіперфосфатемія } & $<1,78$ & 63 & 74 & 36 & 60 \\
\hline & $>1,78$ & 22 & 26 & 24 & 40 \\
\hline \multirow[t]{2}{*}{ Рівень альбуміну плазми } & $<35$ Г/л & 2 & 2,5 & 13 & 22 \\
\hline & $>35$ Г/л & 83 & 97,5 & 47 & 78 \\
\hline \multirow[t]{3}{*}{ Загальний кальцій плазми } & $<2,1$ & 5 & 6 & 9 & 15 \\
\hline & від 2,1 до 2,54 & 73 & 86 & 39 & 65 \\
\hline & $>2,54$ & 7 & 8 & 12 & 20 \\
\hline \multirow[t]{3}{*}{ Діалізна доза КT/V } & $\mathrm{KT} / \mathrm{V}<1,2$ & 6 & 7 & 11 & 19 \\
\hline & від 1,2 до 1,4 & 11 & 13 & 49 & 81 \\
\hline & $\mathrm{KT} / \mathrm{V}>1,4-1,7$ & 68 & 80 & 0 & 0 \\
\hline
\end{tabular}

Аналізуючи тривалість життя пацієнтів в залежності від тривалості, часу та індивідуального підбору профілю діалізних розчинів, ми відмітили, що в групі 3 індивідуально підібраними програмами кількість людей, котрі живуть, отримуючи діалізну терапію, більше 5 років, суттєво переважає, порівняно із групою, у якій застосовували стандартні схеми діалізу.

В обох групах хворих спостерігали анемію, проводили еритропоетинотерапію, однак необхідність пї застосування частіше виникала в другій групі. Кращі результати при використанні значно менших доз еритропоезстимулювальних препаратів отримано в групі, де діаліз проводився за індивідуальними програмами.

Проводили також аналіз рівня гіперфосфатемії. У пацієнтів з індивідуально підібраними програмами вона також виражена значно менше, ніж у пацієнтів другої групи (табл. 3).

Що стосується показників діалізної дози КT/V, то виявилось, що важлива для тривалого і якісного життя діалізна доза краще досягається при більш тривалому за часом діалізі та при індивідуально підібраних програмах по діалізату (табл. 3).

Порівнявши показники рівня альбуміну плазми в групі пацієнтів, у яких лікування проводилось за індивідуально підібраними програмами, з тими ж при застосуванні стандартних методик, ми виявили, що ці показники були суттєво кращими в групі з більш тривалим діалізом.

Визначаючи рівень загального кальцію крові пацієнтів, ми виявили, що в I групі, де була більша тривалість сеансів гемодіалізу, рівні його більше наближались до бажаних, ніж у II групі (табл. 3).

Висновки. Основною причиною летальності пацієнтів, які отримують лікування методом гемодіалізу, є серцево-судинна патологія. Існують фактори ризику смерті від серцево-судинних захворювань у пацієнтів, що отримують лікування сеансами програмного гемодіалізу.

При проведенні лікування сеансами програмного гемодіалізу, моделюючи індивідуальні програми пацієнтам за часом тривалості діалізу, кліренсовими характеристиками діалізатора, електролітними та температурними властивостями діалізуючого розчину, можна отримати зменшення потенційно модифікованих показників ризику серцево-судинних захворювань у порівнянні з пацієнтами, які отримують стандартні процедури гемодіалізу. Це свідчить про необхідність вивчення моделювання індивідуальних програм проведення лікування сеансами гемодіалізу з метою зменшення потенційно модифікованих ризиків розвитку серцево-судинної патології у пацієнтів, котрі отримують лікування методами ниркової замісної терапії. 


\section{Література}

1. Kidney Disease as a Risk Pactor for Development of Cardiovascular Disease / Mark J. Sarnak, MD, Cochair; Andrew S. Levey, MD, Cochair; Anton C. Schoolwerth, MD [et al.] // Am JKidney Dis - 2000. - Vol. 35 (Suppl I)

2. Baseline blood pressure and other variables influencing survival on haemodialysis of patients without overt cardiovascular disease / J.J.G. De Lima, M.L.C. Vieira, H. Abensur [et al.] // Nephrol. Dial. Transplant. - 2001. - Vol. 16. - P. 793-797.

3. Прогностическое значение контролируемой и неконтролируемой артериальной гипертонии у больных с терминальной хронической почечной недостаточностью, находящихся на хроническом гемодиализе / Милованова Л. Ю., Николаев А. Ю., Лифшиц Н. Л. [и др.] // Терапевт. архив - 2002 . - Т. 74. - № 6. - С. 45-49.

4. Non-high-density lipoprotein cholesterol (non-HDL-C) as a predictor of cardiovascular mortality in patients with end-stage renal disease /Y. Nishizawa, T. Shoji, R. Kakiya [et al.] // Kidney Int. - 2003. - Vol. 63. - Suppl. 84. - P. 117-120.

5. Pulse pressure and risk of total mortality and cardiovascular events in patients on chronic hemodialysis / M. Tozawa, K. Iseki , C. Iseki [et al.] // Kidney Int. - 2002. - Vol. 61. P. 717-726.
6. Clinical and echocardiography disease in patients starting end-stage renal diseasetherapy / R. N. Poley, P. S. Parfrey, J. D. Harnett [et al.] // Kidney Int. - 1995. - Vol. 47. - P. 186192.

7. Can we improve early mortality in patients receiving renal replacement therapy / W. Metcalfe, I.H. Khan, G.J. Prescott [et al.] // Kidney Int. - 2000. - Vol. 57. - P. 2539-2545.

8. Body size, dialysis dose and death risk relationships among hemodialysis patients / E.G. Lowrie, Li Z., N. Ofsthun [et al.] // Kidney Int. - 2002. - Vol. 62. - P. 1891-1897.

9. Survival as an index of adequacy of dialysis / B. Charra, E. Calemard, C. Chazot [et al.] // Kidney Int. - 1992. - Vol. 41. P. 1286-1291.

10. Long-term experience with an ultrapure individual dialysis fluid with a batch type machine / W. Kleophas, B. Haastert, G. Backus [et al.] // Nephrol. Dial. Transplant. - 1998. -Vol. 13. - P. 3118-3125.

11. Kopple J.D. McCollum award lecture, 1996: Protein-energy malnutrition in maintenance dialysis patients / J.D. Kopple // Am. J. Clin. Nutr. - 1997. - Vol. 65. - P. 1544-1557.

12. Predictors of poor outcome in chronic dialysis patients: the Nederlands cooperative study on the adequacy of dialysis / M.P. Merkus, K.J. Jager, P.W. Dekker [et al.] //Am. J. Kidney Dis. - 2000. - Vol. 35. - P. 69-79. 